\title{
IMÁGENES, ALHAJAS, ORNAMENTOS Y MOBILIARIO DE LA COMPAÑÍA DE JESÚS EN MURCIA. INVENTARIO Y DISTRIBUCIÓN DE SUS BIENES TRAS LA EXPULSIÓN DE 1767
}

\author{
IMAGES, SILVERWARE, ORNAMENTS AND \\ FURNITURE FROM THE SOCIETY OF JESUS IN MURCIA. \\ INVENTORY AND DISTRIBUTION OF ITS GOODS \\ AFTER THE EXPULSION IN 1767
}

Ignacio José García Zapata

Universidad de Granada

\section{RESUMEN}

La expulsión de los jesuitas en 1767 supuso la puesta en marcha de un amplio sistema administrativo centrado en la gestión de las posesiones que habían pertenecido hasta entonces a la Compañía de Jesús. Uno de los cometidos que tenían que llevar a cabo estos consejos estaba centrado en el inventariado y distribución de las alhajas y ornamentos que esta orden tenía en sus colegios e iglesias. En el caso de Murcia, el inventario efectuado para tal fin, ofrece una panorámica general del estado en el que se encontraba la Iglesia de San Esteban aquel año. Asimismo, la documentación conservada refleja el destino de algunas alhajas y ornamentos que, siguiendo las indicaciones reales, fueron divididas y distribuidas, quedando algunas en el templo original, pasando otras a las parroquias pobres y llegando otras al convento franciscano de Santa Catalina del Monte. En este artículo se analiza este inventario, así como la distribución de sus alhajas y ornamentos, conforme a lo que sucedió en otros territorios españoles, incluyendo el propio caso de Caravaca de la Cruz, con el fin de ofrecer una visión global.

Palabras clave: Jesuitas/Murcia/inventario/alhajas/ornamentos...

\section{ABSTRACT}

The expulsion of the Jesuits in 1767 entailed the setting up of a broad administrative system focused on the management of the goods heretofore belonging to the Society of Jesus. Among the tasks that these councils were meant to accomplish appears the inventory and distribution of the silverware and ornaments that had been preserved by this order in its colleges and churches. In the case of Murcia, the executed inventory for that purpose offers an overview of the state of the Church of San Esteban in that year. Additionally, the documentation preserved reflects the destination of the silverware and ornaments: some of them were kept in the temple, some were sent to poorer parishes and some ended up in the Franciscan convent of Santa Catalina del Monte. This inventory has been analysed in this paper, as well as the distribution of its silverware and ornaments, according to what occurred in other Spanish territories, including the case of Caravaca de la Cruz, with the aim of offering a general picture. Key words: Jesuits/Murcia/inventory/silverware/ornaments... 
La expulsión de la Compañía de Jesús de los territorios españoles, conforme al Real Decreto de 27 de febrero de 1767 y a la Pragmática Sanción del 2 de abril de ese mismo año, trajo consigo la disolución de las instituciones de la orden, el extrañamiento de sus miembros y la ocupación de sus bienes patrimoniales, tanto inmuebles como muebles, entre los que se encontraba un basto conjunto de obras artísticas de gran valor ${ }^{1}$. De este modo, la expulsión puso fin a la amplia red de colegios que la compañía tenía por todos los territorios de la monarquía hispánica. Así, sus colegios e iglesias pasaron a otras manos y muchos de sus enseres, especialmente ornamentos y alhajas, fueron redistribuidos en función de las decisiones adoptadas en cada caso. Para ello, se iniciaron numerosos procesos administrativos consistentes en desmantelar esos centros educativos y religiosos, al tiempo que se abordaban nuevos usos y funciones, y alhajas y ornamentos eran repartidos entre otros templos, siempre siguiendo como patrón común las necesidades de aquellas parroquias más pobres o de nueva construcción, sin descuidar, es decir, dejando lo preciso, en la iglesia jesuita²

El caso particular de Murcia, donde los jesuitas contaban con el Colegio de San Esteban, la iglesia homónima y el Colegio de la Anunciata, ha sido parcialmente estudiado por la investigadora María Trinidad López García. Su pormenorizado estudio, fundamentado en dos importantes legajos conservados en el Archivo General de la Región de Murcia, desentraña perfectamente cómo fue todo el proceso de administración de las temporalidades de los jesuitas, desde la gestión municipal hasta la del propio obispado, siguiendo siempre las directrices marcadas por el intendente-comisionado por el rey para este asunto (López García, 2006)33. A pesar de ello, como la propia investigadora consideró, merece una atención especial el estudio del inventario de los bienes artísticos que poseía la compañía (imágenes, pinturas, ornamentos y alhajas de plata y oro), con el fin de conocer la dotación de su templo, la situación en la que se encontraba en el momento de la expulsión y la consideración con respecto al extraordinario momento histórico-artístico que atravesaba el Reino de Murcia ${ }^{4}$. Asimismo, se tiene en cuenta lo acaecido con los bienes de los jesuitas establecidos en Caravaca de la Cruz, en la iglesia del Colegio de la Anunciata de dicha ciudad, a través del estudio de sus bienes, igualmente referenciados en un detallado inventario efectuado tras la supresión de la orden.

En efecto, los jesuitas, desde su fundación en 1534 por San Ignacio de Loyola, posteriormente refrendada por el papa Pablo III, habían mostrado una especial atención con todo lo referente al culto y a su manifestación. Así, fueron una de las órdenes que mayor interés mostraron por el decoro de sus ornamentos y alhajas, llegando a conformar, a tenor del inventario, uno de los ajuares más relevantes de las órdenes religiosas establecidas en el Reino de Murcia.

1 La bibliografía al respecto de este hecho histórico es bastante abundante, por tanto, nos limitamos a la relación de estas publicaciones, véase: P. RODRÍGUEZ DE CAMPOMANES, Dictamen fiscal de expulsión de los jesuitas de España 1766-1767, Madrid, Fundación Universitaria Española, 1977 (Edición, introducción y notas de J. CEJUDO y T. EGIDO); T. EGIDO, «La expulsión de los jesuitas de España», en A. MESTRE (Coord.), La Iglesia en la España de los siglos XVII y XVIII, Madrid, Biblioteca de Autores Cristianos, Vol. IV, pp. 746-792; E. GIMÉNEZ LÓPEZ (Coord.), Expulsión y exilio de los jesuitas españoles, Alicante, Universidad de Alicante, 1997 y C. A. MARTÍNEZ TORNERO, Carlos III y los bienes de los jesuitas: la gestión de las temporalidades por la monarquía borbónica (1767-1815), Alicante, Universidad de Alicante, 2010.

2 A este respecto son bastantes los casos conocidos y documentos en los que se aborda pormenorizadamente esta cuestión que, con las particularidades propias de cada lugar, se repitió allí donde la Compañía de Jesús tenía presencia, véase, por ejemplo: R. VÁZQUEZ LESMES, «Extrañamiento de los jesuitas y desamortización de sus temporalidades en Córdoba (1767-1769)», en F. J. CAMPOS (Coord.), La desamortización: el expolio del patrimonio artístico y cultural de la Iglesia en España, Alicante, Biblioteca Virtual Miguel de Cervantes, 2011, pp. 241-258.

3 A su detallado estudio nos remitimos para las cuestiones administrativas y otros detalles de carácter jurídico. En relación con la documentación del Archivo General de la Región de Murcia, toda la documentación sobre el proceso, autos, diligencias, órdenes, inventarios... se encuentra en el Fondo IAX, Sig. 1377/1 y 1377/2, leg. 14, $\mathrm{n}^{\circ} 1$ y 2 de la antigua signatura. Este último está completamente digitalizado y en abierto en la web del archivo.

4 Son numerosas las publicaciones que en los últimos años se han centrado en el estudio de los inventarios de alhajas y ornamentos como una fuente principal para el análisis de su composición y evolución, véase: M. PÉREZ SÁNCHEZ, «La significación del inventario en el estudio de los tesoros catedralicios: el ejemplo de la Catedral de Murcia a través del inventario del Tesoro de 1807», en J. RIVAS CARMONA (Coord.), Estudios de Platería. San Eloy 2004, Murcia, Universidad de Murcia, 2004, pp. 445-466; M. A. RAYA RAYA, «La importancia de los inventarios en el estudio de la platería: el inventario de 1507 de la Catedral de Córdoba», en J. RIVAS CARMONA (Coord.), Estudios de Platería. San Eloy 2005, Murcia, Universidad de Murcia, 2005, pp. 611-629; I. J. GARCÍA ZAPATA, «La importancia de los inventarios en el estudio de la platería catedralicia. Los inventarios del Sagrario, de 1588 y 1619, de la Santa Iglesia Catedral Primada de Toledo. Oro, plata y piedras preciosas», en M. E. ALMARCHA, P. MARTÍNEZ-BURGOS y M. E. SAINZ (Coord.), El Greco en su IV Centenario: patrimonio histórico y diálogo intercultural, Toledo, Universidad de Castilla-La Mancha, 2016, pp. 1025-1039 y M. S. LÁZARO DAMAS, «La platería de la Catedral de Guadix y el inventario de la sacristía de 1613», en J. RIVAS CARMONA e I. J. GARCÍA ZAPATA (Coords.), Estudios de Platería. San Eloy 2018, Murcia, Universidad de Murcia, 2018 , pp. $279-292$. 
Los jesuitas se ubicaron en los principales núcleos urbanos del reino, como en Murcia, Cartagena, Caravaca de la Cruz y Lorca, donde fundaron sus colegios desde mediados del siglo XVI y hasta los primeros compases del Setecientos, por ejemplo, en Lorca no se instalaron definitivamente hasta 1713. Con todo, fue en Murcia, como cabeza de la diócesis de Cartagena y principal ciudad del reino, donde los regulares tuvieron una presencia más importante a través del Colegio de San Esteban y su iglesia, un centro docente que fue erigido por deseo del obispo Esteban de Almeida, un importante prelado del siglo XVI que obtuvo la autorización del fundador de la orden para crear un colegio de la compañía en Murcia, cuya construcción de prolongó entre los años 1555 y 1569. A este primer núcleo se sumó poco después el Colegio de la Anunciata. De este modo, los jesuitas pronto convirtieron su colegio en el centro de referencia de los estudios y del conocimiento humanista en la capital del reino, impartiendo teología, escolástica, escritura, gramática y filosofía, entre otras materias, que hicieron de él el principal centro de formación de los nombres más destacados de la historia de este reino durante el tiempo que permaneció en activo (Gutiérrez-Cortines Corral, 1976 y Gutiérrez-Cortines Corral, 1998: 491-514)5. De hecho, uno de los inventarios que se efectuaron con motivo de la expulsión y que sí ha contado con una investigación más detallada fue el relativo a la importante biblioteca que la compañía poseía en el Colegio de San Esteban. Una relevante colección, formada por un elevado número de obras de diversas materias, que constituía la base del sistema educativo de los jesuitas, como instrumento que permitía dar una formación más amplia a sus alumnos, al tiempo que completaba la del clero (Játiva Miralles y Herrero Pascual, 2007: 19-25 y Játiva Miralles, 2008).

Comunicada la noticia de la expulsión a los miembros de la compañía establecidos en Murcia, pronto se decidió que sus edificios tuvieran otros fines. El Colegio de San Esteban cambió su utilidad, convirtiéndose en la nueva sede del Real Hospicio y Casa de Misericordia, con su templo para cumplir con las cargas espirituales del referido hospicio, motivo por el cual hubo que dejarle algunos ornamentos y alhajas. Por su parte, el Colegio de la Anunciata pasó a ser una escuela de primeras letras, latinidad y retórica, con habitaciones para los maestros que allí impartían docencia.

El inventario detallado de los bienes, alhajas, ornamentos y mobiliario litúrgico de la compañía se llevó a cabo los días 25 de octubre y 3 de noviembre de 1769, cumpliendo así con la disposición real y con las instrucciones dadas a tal efecto, que apuntaban cómo las alhajas de las sacristías e iglesias se tenían que inventariar con la asistencia de determinadas autoridades, tratándose con el respeto y la decencia que requieren los vasos sagrados, sin irreverencia ni menor acto contrario a la religión. Aquella jornada se reunieron en la sacristía los responsables de las administraciones locales y eclesiásticas nombradas para todo lo relativo a la apropiación de las temporalidades de los jesuitas. En concreto, para el repartimiento de los ornamentos y alhajas se dieron cita don Juan García, cura propio de la iglesia parroquial de la Catedral de Santa María, quien en nombre del obispo -el cual había excusado su ausencia y delegado en él sus funciones- hizo la separación de los objetos de culto, y el notario episcopal. Ambos, a su llegada al colegio se encontraron, entre otros, con don Alberto Suelbas, intendente corregidor de la ciudad y el reino; don Juan José Mateos, canónigo de la catedral y don Joaquín Saorín, los dos comisionados por la junta municipal de temporalidades; don Pablo Franco, presbítero y capellán del Real Hospicio y don Diego Antonio Calleja, secretario del Concejo ${ }^{6}$.

El inventario recoge puntualmente todas las esculturas, pinturas, ornamentos, alhajas y el mobiliario que se encontraba repartido por las dependencias del colegio y su iglesia, así como otros objetos de menor significación, caso de las populares alfombras de Liétor. Sin duda, esta relación constituye un testimonio elocuente del estado en el que se encontraba el templo y sus capillas aquel año de 1769, más si cabe después de los cambios que con el paso de los años se fueron dando en el templo. Evidentemente, la imaginería y las pinturas respondían a las propias devociones de los jesuitas, a sus santos y cultos más arraigados, como puede ser

5 En relación a la construcción del Colegio de San Esteban y de su templo nos remitimos a los estudios de a profesora Gutiérrez-Cortines.

6 Archivo General de la Región de Murcia (en adelante AGRM), Fondo IAX, Sig. 1377/2, s.n. (Signatura antigua, leg. 14, n 2) 
el caso de un cuadro grande con marco negro de los tres mártires del Japón dispuesto en la Capilla de San Francisco de Borja. Lo mismo ocurre en cada uno de los espacios, donde los santos jesuitas son los predominantes junto a las imágenes de la Virgen y otros santos habituales.

Más allá de las piezas que componían el ajuar textil y las alhajas de plata, que se verán más adelante, el inventario constituye un rico testimonio para conocer qué otros objetos se hallaban en el templo, especialmente en lo relativo al mobiliario litúrgico, sobre todo en lo relativo a sus retablos y otras piezas varias que formaban parte de cada una de las capillas del templo, como las esculturas ${ }^{7}$. Al respecto pueden mencionarse las descripciones, muy concisas pero suficientes, de los retablos dieciochescos de cada una de las capillas, con sus imágenes, donde incluso se permiten alguna licencia, como por ejemplo a la hora de mencionar el grupo escultórico del calvario, formado por las imágenes de la Dolorosa, San Juan y del Crucificado de la Capilla del Santo Cristo, talla que calificaron de primorosa ${ }^{8}$.

Otro ejemplo es la composición de la Capilla de San Javier, donde había un altar con su ara, un atril de madera viejo, las sacras con marcos dorados, un sagrario también en madera, dorado y viejo, una cruz del mismo material con embutidos de nácar, al parecer de Jerusalén $\mathrm{y}$ varios relicarios insertos en el retablo, algunos con cristales y otros no, lo que da una idea del estado en el que se encontraban. Asimismo se describe el relevante retablo de la Capilla de Nuestra Señora del Socorro, del que se menciona que es de talla dorada y los lisos jaspeados en azul, con las esculturas de San Joaquín y Santa Ana dispuestas en nichos de espejo con sus cubiertas en lienzo con pinturas de las mismas imágenes - posiblemente se refiere a los bocaportes-. Encima de este retablo una imagen de medio cuerpo en cuyo pecho se abría un relicario que contenía las reliquias de un santo mártir - debe de tratarse de San Juan Eudes-, y rematando dicho retablo, un lienzo de San José con el Niño. El retablo comprendería tanto el testero de la capilla como los colaterales, donde estarían dispuestos dos grandes cuadros con escenas de la vida de la Virgen, el nacimiento y la asunción, de Antonio de la Fuente?

También son interesantes las descripciones de algunas piezas muy concretas, caso de un tabernáculo de la Capilla del Santo Cristo, realizado en madera tallada y sobredorada, con puerta de cristal tras la que había una lámina pequeña de piedra ágata, con una imagen de la Purísima Concepción con los llanos de vidrio, mitad lapislázuli el marco de ágata morada, toda guarnecida de metal dorado en fuego y sobrepuesto de lo mismo, con antorchados de plata en blanco. En otra de las capillas, en este caso en la de San Ignacio, se hallaba una urna de madera, con molduras doradas y jaspeadas, con puerta de cristal y lo mismo a los lados, y dentro una lámina pintada con la imagen de medio cuerpo de la Virgen con el Niño.

En el caso de la platería, entre las piezas inventariadas destacan las que se hallaban en dos arcas localizadas en una sala situada en el atrio de la casa, fuera de la sacristía ${ }^{10}$. En estas arcas se encontraron por un lado las piezas destinadas a las celebraciones y al culto eucarístico, como una custodia sobredorada y guarnecida con algunas piedras, de once onzas y cinco

7 Al respecto de los retablos de la Iglesia de San Esteban, véase: M. C. de la PEÑA VELASCO, El retablo barroco en la antigua diócesis de Cartagena (1670-1785), Murcia, Colegio Oficial de Aparejadores, 1992, pp. 176, 241, 253, 254, 271 y 374.

8 Nos referimos a la hechura del maestro Domingo Beltrán de Otazu, realizada a finales del siglo XVI, y que ahora se conoce como Cristo de la Misericordia.

9 En el inventario no se hace diferenciación entre la Capilla de San Francisco y la de Nuestra Señora del Socorro, aunque debe de tratarse simplemente de un olvido a la hora de anotar en el margen izquierdo el espacio. Tampoco se menciona en el inventario la escultura del Socorro que debía de estar en el camarín, imagen que fue llevada a la catedral en 1767, lo que explicaría su ausencia en el inventario. Fuentes y Ponte sí alude en su descripción de esta capilla a la presencia de una escultura en el interior del camarín, dentro a su vez de un templete con columnas salomónicas, de una imagen de Nuestra Señora de la Luz con el Niño, como por entonces se conocía ya la capilla, que era una imagen de talla que habían hecho de vestir. Las esculturas, junto a otras obras del templo, se encuentran hoy en el Museo de Bellas Artes de Murcia y en San Juan de Dios, quedando los retablos en su emplazamiento original del templo de San Esteban. En el museo se expone una escultura identificada como San Isidro Labrador que en antiguas fotografías ocupaba ese espacio encima del vano del camarín. A ella también hace alusión Fuentes y Ponte, aunque no dice que se encuentre exactamente en ese punto, sino sobre las gradas. Con todo, la profesora De la Peña ya consideró que sobre esa atribución había dudas, y si el inventario es correcto, esa imagen sería la de un santo mártir, aunque también cabe la posibilidad de que la escultura de San Isidro Labrador se pusiera en fechas posteriores a la redacción del inventario, ya que menciona una imagen con relicario en el pecho, algo que no se ve en la de San Isidro Labrador.

10 En el inventariado de las alhajas de plata posiblemente, aunque nada se indica al respecto en la documentación, participará algún platero, pues todas aparecen con su peso, y se ha constatado cómo en otras ciudades se contaron con maestros plateros para este fin, caso de Salamanca, donde en el inventario de las piezas de plata del colegio de los jesuitas de esta ciudad participó el maestro platero Alonso del Prado, véase: M. A. SÁNCHEZ GÓMEZ, «El Colegio de Jesuitas de Santander. Vida material y patrimonio», Hispania Sacra, ñ 142, 2018, p. 585 y 591. 
libras de peso, un par de copones, seis cálices con sus patenas, también de plata y alguno más en bronce, tres juegos de vinajeras y otras piezas imprescindibles en cualquier templo, caso de una cruz de plata con las imágenes de Cristo y la Inmaculada Concepción grabadas, siendo esta una de las pocas piezas de las que se ofrece una descripción algo más profunda, pues el resto de entradas solo precisan el objeto, material y peso. La relación prosigue, sin hacer distinción en el espacio, por tanto, recogiendo aquellas piezas que se encontraban en las dos arcas ya citadas, enumerando varias lámparas y arañas de plata que pertenecían a diferentes capillas del interior de la iglesia. El motivo por el que se encontraban en los arcones y no en sus capillas se desconoce, quizás las habrían agrupado para evitar su pérdida en aquellos meses confusos tras la expulsión de los jesuitas. En resumen había media docena de arañas y casi una decena de lámparas, entre ellas una con el rótulo de la congregación y otra de doce onzas y nueve libras que sería la más grande del templo y se ubicaría en la capilla mayor. También llaman la atención seis ramos de flores en plata blanca y un ramo de azucenas que se usaban para el ornato de la imagen de San Javier.

La presencia de plata no concluye con las alhajas de estas dos arcas, pues el 3 de noviembre continuó la confección del inventario con la anotación de las imágenes, objetos y otras cosas que se encontraban en el interior del templo, que fue descrito capilla por capilla, mencionándose en cada caso las esculturas, pinturas, retablos, ornamentos y otras piezas que había en ellas. Así, al describir algunas de estas hechuras se pueden mencionar otras piezas de plata que completaban el exorno de diversas imágenes. Por ejemplo, la talla de la Dolorosa de la Capilla del Santo Cristo contaba con espada y diadema de este material, así como la gran imagen de San Francisco de Borja de su capilla, que tenía diadema de plata.

En lo que respecta a los ornamentos textiles, tampoco existen piezas de gran relevancia, quizás por la parquedad de las descripciones del inventario. Por supuesto, sí se hace evidente en la relación el numeroso conjunto de ornamentos, entre los que sobresale la elevada cifra de casullas, cerca de la treintena, y de frontales, con los que cubrir los altares de capilla en función del tiempo litúrgico. Estas piezas se encontraban situadas en el mobiliario dispuesto en el testero de la sacristía, donde se disponían diversas cajoneras con todos los ornamentos, aunque también encontramos otros repartidos por diversas estancias, metidos en arcas, o en las capillas. Destaca la presencia de solo tres ternos completos, dos de ellos en seda guarnecidos con oro y plata, así como una capa pluvial que contaba con cuatro gafetes de plata y, finalmente, una colgadura de damasco y terciopelo carmesí compuesta por cuarenta paños dispuestos en los pilares de la Capilla Mayor, descritos como de todo lucimiento y decencia. No obstante, parece que el estado de los ornamentos no era el más adecuado, o eso se puede interpretar a tenor de la intervención del sastre Joseph Ponzoa en enero de 1770, cuando fue contratado por don Juan García para que aderezara varias casullas de la sacristía del templo jesuita, por cuyo trabajo recibió 204 reales de vellón.

El destino de las alhajas y ornamentos tuvo cuatro direcciones distintas. Todo el mobiliario del colegio, el relativo a los dormitorios y cocinas, se quedó para uso del hospicio. Por otro lado, algunas alhajas y ornamentos fueron destinados a las parroquias más pobres de la diócesis. Con ello se cumplía una de las directrices fijadas en la Pragmática Sanción de Carlos III, la cual precisaba cómo los bienes de la Compañía de Jesús debían de aplicarse en obras pías, como era la dotación de parroquias pobres, seminarios o casas de misericordia, siempre atendiendo a las propuestas del poder eclesiástico local donde tuviera lugar ese repartimiento. Así pues, acordaron destinar una serie de alhajas y ornamentos a las parroquias más necesitadas de la diócesis, operación de la que se ocupó directamente don Juan García, quien apartó para este fin, entre otros ornamentos, veinticinco casullas de colores verde, morado, encarnado y blanco, treintas sobrepellices, tres cálices de plata con sus patenas, uno de ellos con el pie de bronce, y unas vinajeras. Las parroquias beneficiadas de esta distribución aparecen igualmente referenciadas en los documentos, dado que los párrocos o sacristanes de estos templos emitían certificado de recepción. De esta lista se desprende cómo la mayoría eran parroquias menores o ermitas, por lo general de la Huerta de Murcia y del Campo de Cartagena, aunque también se beneficiaron otras más alejadas de Murcia, como la parroquia de San Javier o la de Isso, cerca de Hellín. No obstante, la más beneficiada fue la Ermita de Santiago de Murcia, dependiente de la parroquia de San Miguel, adyacente al propio colegio 
jesuita. A ella fueron a parar un cáliz, con su patena y cucharita y unas vinajeras, todo de plata, un misal, tres casullas, un alba y otras cosas menudas. Asimismo, los lugares que más piezas recibieron fueron aquellos templos dependientes de la parroquial de la catedral, iglesias que vieron mejorados sus ajuares con estas alhajas y ornamentos procedentes del repartimiento de los bienes de los jesuitas de Murcia.

Lo mismo sucedió en el resto del país, dado que la orden relativa a la distribución de los bienes de los jesuitas fue igual para todo el territorio, si bien con pequeñas diferencias. Por ejemplo, las cosas de los jesuitas de algunos territorios de Andalucía se destinaron a la dotación de los templos de las Nuevas Poblaciones, conforme a su fuero, pues sus parroquias, de reciente creación, precisaban más si cabe de esos vasos sagrados y ornamentos (Capel, 1970: 88). De hecho, el ajuar de la iglesia de Fuente Palmera se hizo con los bienes de los templos y colegios que la compañía tenía en Córdoba, Carmona, Marchena y Écija (VV. AA., 1981: 109). En otras ocasiones fueron ya a templos importantes, pues a la Colegiata del Divino Salvador de Sevilla se incorporó un altar de plata procedente de la iglesia jesuita de la Encarnación de la capital hispalense (Santos Márquez, 2011: 529).

Al respecto del reparto de las alhajas de plata, debió de surgir algún tipo de controversia en algún punto de España dado que, a comienzos de diciembre de ese año, llegó una nueva notificación desde Madrid rubricada por Campomanes en la cual se especifica sobre el tema. En concreto, venía a puntualizar acerca de las piezas de plata que debían donarse. De hecho, confirmaba que efectivamente era obligatorio repartir las alhajas y ornamentos, pero especificando que debían de ser únicamente los vasos sagrados, es decir, cálices, copones y patenas, y que el resto de obras de plata, aquellas que no sirviesen inmediatamente para el culto, no estaba permitido darlas, es más, de ellas se pedía una relación, que tenían que remitirle a Campomanes a la mayor brevedad. En este sentido, el caso de Utrera es bastante claro al respecto en cuanto a la división de las alhajas (Martín Pradas y Carrasco Gómez, 2016: 53-58).

Se desconoce si en Murcia se realizaron nuevos inventarios para dar debido cumplimiento a estas premisas. Con todo, a tenor del inventario, no parece que las alhajas de este segundo grupo fueran muy numerosas, más allá de unas cuantas lámparas y arañas de plata. Las cuales, según las indicaciones recibidas desde Madrid al año siguiente, tendrían que estar en un lugar seguro a disposición del Consejo ${ }^{11}$. Es de suponer que el resto de alhajas y ornamentos, es decir, aquellos que no se habían repartido entre las parroquias más necesitadas ni que habían quedado bajo control del Consejo, quedaron para cubrir las necesidades cultuales del hospicio.

Esta puntualización sí fue atendida en el caso de las piezas de plata que los jesuitas poseían en el Colegio de la Anunciata de Caravaca de la Cruz, pues el inventario efectuado en 1773 sí divide las piezas en dos bloques. El primero de ellos aglutina los vasos sagrados, una custodia, una cruz, una urna con la reliquia de San Bartolomé, una ampolla para los óleos y algunas piezas del ajuar de las imágenes, como una corona de plata, unas potencias y una diadema con una piedra azul en el centro, de San Francisco Javier. Posiblemente estas fueron las alhajas que se quedaron para el servicio del templo tras la salida de los regulares, mientras que aquellas enmarcadas en un segundo bloque, un incensario con su naveta y cuchara, dos ciriales, seis candeleros y cuatro vinajeras con dos platillos y una campanilla, serían las que quedarían a disposición del Consejo ${ }^{12}$.

En último lugar, los responsables del proceso en la capital del reino recibieron la solicitud de los franciscanos del Convento de Santa Catalina del Monte para que se aplicaran a su templo un retablo, cuatro cuadros, las aras y demás alhajas del adorno y culto de un oratorio que los regulares de la compañía tenían en la hacienda llamada de las Ermitas. Efectuadas las diligencias oportunas y elaborado el inventario pertinente, en marzo de 1772 se procedió con la entrega de estos bienes a los franciscanos de este convento, quienes además de los solicitado recibieron la totalidad de las imágenes, alhajas, ornamentos y mobiliario del citado oratorio.

11 Del destino final de estas alhajas nada se ha documentado hasta el momento.

12 Archivo Municipal de Caravaca de la Cruz, leg. 194, n 18, s.n. 
De esta forma los bienes del Colegio de San Esteban de la Compañía de Jesús fueron repartidos por diferentes parroquias y ermitas, así como en el Convento de Santa Catalina del Monte, pasando a integrar los ajuares de otras iglesias, bajo el pretexto de las necesidades que tenían, dando así cumplimiento a las órdenes emitidas en relación con las temporalidades de los regulares. Por supuesto, la Iglesia no iba a permitir que los elementos más sagrados para el culto se enajenaran, cuidando que los vasos sagrados tuvieran un uso práctico allí donde se precisaban, si bien es cierto que aquellas piezas no vinculadas directamente con el culto, como las lámparas, quedaron a disposición del Consejo. Con todo, la iglesia de San Esteban mantuvo un ajuar con el que cumplir con sus funciones, pues continuó siendo un lugar de culto. Incluso, se ha documentado un nimbo neoclásico del platero cordobés José Heller, realizado en el siglo XIX, que llegó a la Iglesia de San Juan de Dios en el siglo XX procedente de San Esteban, junto a otras cosas (Rivas Carmona, 1999: 255). A pesar de ello, para entonces el ajuar del templo jesuita ya debía de estar muy mermado, pues González Simancas ya advirtió en el Catálogo Monumental de España dedicado a la provincia de Murcia, que los ornamentos y objetos de plata presentes a comienzos de la pasado centuria en el templo de San Esteban eran modernos y de escaso valor artístico, lo que nos da una idea de cómo estaba el ajuar por entonces (González Simancas, 1905: 203).

Al templo de San Juan de Dios también llegó hace unas décadas procedente de la Iglesia de San Esteban un ostensorio atribuido al escultor Francisco Salzillo y fechado en la década de los sesenta del siglo XVIII. En el inventario no se ha identificado dicha pieza. Quizás, el ostensorio llegara al templo de San Esteban después de la expulsión de los jesuitas o, como señaló Sánchez Moreno, originariamente estuviera en el templo de San Antón y solo más tarde se incorporó al ajuar de San Esteban. Ni Fuentes y Ponte ni González Simancas, cuando describen el templo de San Esteban, hacen referencia a ese ostensorio, aunque en otras ocasiones se ha dicho que ese objeto se dispuso en el camarín de la Capilla del Socorro, pero, insistimos, salvo que fuera después, eso no parece que sucediera, pues Fuentes y Ponte precisa que allí se hallaba una imagen mariana (Fuentes y Ponte, 1880: 95-96). Con todo, resulta llamativo que los jesuitas, escrupulosos con el culto y su manifestación, permitieran la exposición del Santísimo Sacramento en un objeto de madera. Incluso, cuando se conocen testimonios en la propia Catedral de Murcia en los que se renuevan ciertas piezas por estar realizadas en materiales que no responden a la debida pertinencia y majestad del culto ${ }^{13}$. Al respecto de esta obra, también habría que reflexionar si realmente se trata de un ostensorio para la exposición del cuerpo de Cristo, como hace pensar el sol de la parte superior -quizás excesivamente grande- al que dirige su mirada uno de los ángeles, ya que en el centro del cuerpo inferior se abre una teca que parece dispuesta para albergar alguna reliquia, en cuyo caso, no se concebiría que un ostensorio tuviera esta doble función y dividiera la atención que la Sagrada Forma requería como eje fundamental del culto con la presencia de una reliquia ${ }^{14}$.

\section{ANEXO DOCUMENTAL INVENTARIO DE IMÁGENES, ALHAJAS Y ORNAMENTO QUE TENÍA LA COMPAÑÍA DE JESÚS DE MURCIA}

En la ciudad de Murcia en veinte y cinco días del mes de Octubre de mil setecientos sesenta y nueve años en cumplimiento de dicho auto el señor don Juan García comendador cura propio de la parroquial de Santa María Catedral de esta ciudad, vicario foráneo, y juez comisionado para estas diligencias asistido de mi el notario, paso a el Colegio y Casa que en esta dicha tuvieron los regulares de la Compañía del Santo Nombre de Jesús y sacristía de ella en donde se hallaba el señor don Alberto de Suelbos intendente corregidor de esta ciudad y su reino; don Juan Joseph Matheos canónigo de dicha Santa Iglesia, don Joaquín Saorin, don Pablo Franco presbítero y capellán de dicho Real Hospicio, don Diego Antonio Callejas, secretario

13 El copón atribuido a Gaspar Lleó de la Catedral de Murcia vino a sustituir un viejo copón de metal y cristal que servía para la reserva del Santísimo en el sagrario del altar mayor, pero que ya estaba deteriorado, era frágil y no respondía a lo que el culto requería. De hecho, el planteamiento inicial era donarlo a la parroquia de San Miguel, idea que finalmente se descartó debido a su estado, véase: I. J. GARCÍA ZAPATA, La orfebrería en el antiguo Reino de Murcia. Diócesis de Cartagena. Murcia, Universidad de Murcia, 2019, p. 234 (Tesis Doctoral).

14 Agradecemos al profesor D. Manuel Pérez Sánchez, de la Universidad de Murcia, la apreciación realizada a este respecto. 
del ayuntamiento de esta dicha ciudad y otros y por dicho señor intendente se separaron las ropas que había en dicha sacristía y de más ornamentos que se hallaban en ella y enterado de ello el referido señor don Juan García Comendador hizo entrega al citado don Pablo Franco de todos los bienes siguientes---

Primeramente un cajón de vestuario con su parapeto y cajones para el vestuario que ocupa todo el testero de la sacristía y su tarima y dentro de dichos cajones lo siguiente:

Un terno compuesto de casulla, dalmáticas, capa pluvial, paño de púlpito, estolas y manípulos correspondientes, bolsa de corporales y paño de cáliz todo de tela de seda y también atrilera, campo blanco flores de oro y matiz guarnecido de galón de oro estrecho y también fleque de oro, el paño del púlpito y atrilera y forrado en tafetán color garrota a excepción de la estola, manípulo y atrilera que lo está en tafetán pajizo---

Una banda de tafetán blanco con fleque de plata del uso del terno antecedente---

Otro terno compuesto de casulla, dalmática, capa pluvial, paño de púlpito, atrilera, bolsa de corporales y cubre cáliz y frontal de tela de seda, campo encarnado, flores de matiz con plata, guarnecido todo con galón de oro y el paño de púlpito, atrilera y frontal con fleque de oro, además de dicho galón---

Una capa pluvial de raso liso, blanco, bordada de bastidor de oro y matiz guarnecido de galón de oro estrecho con cuatro gafetes de plata usada---

Un paño de púlpito de Damasco blanco, nuevo, guarnecido de galón y fleque de seda dorada y el escudo de la Religión bordado de lo mismo---

Otro frontal de tela de oro nuevo, campo verde, y matiz guarnecido de galón de oro estrecho---

Dos casullas de la misma tela del frontal antecedente con sus estolas, manípulos, bolsas de corporales, forrado todo en tafetán pajizo, y guarnecidos en galón de oro estrecho---

Una casulla con manípulo, estola, bolsas de corporales de restaño de plata bordadas, de realce de oro y flores de matiz, guarnecido el cubre cáliz de encaje de oro estrecho y forrado todo de tafetán, encarnado con entre bayetas blancas para su conservación---

Una bolsa de corporales y un cubre cáliz sueltos, de raso liso blanco, bordado de oro y matiz guarnecida de galón estrecho, el paño---

Otro paño de cáliz y bolsa de raso liso blanco, bordado de seda de matiz con galón de plata, el paño---

Tres casullas con tres bolsas, tres paños de cáliz, tres estolas y tres manípulos de clave de plata blanco y encarnado, guarnecidas de encaje de oro estrecho y forrado con tafetán encarnado---

Otra casulla, estola, manípulo, bolsa y paño de tela de oro carmesí y flor de matiz guarnecida de galón de oro entre ancho, todo usado---

Otras cinco casullas con sus estolas, paños, bolsas y manípulos de seda carmesí y blanco guarnecidas de galón de oro falso---

Otras seis casullas con sus bolsas, manípulos y estolas, con sus paños de brillante de color garrota, con perfil y flores menudas, azules y aguas de color de azufre guarnecidas y de galón de oro estrecho---

Otras dos casullas de damasco blanco, con sus manípulos, estolas, paños y bolsas guarnecido todo de galón de oro estrecho---

Otra casulla de tela encarnada con algunas flores de matiz, estola y manípulo, con galón de seda blanca vieja---

Otra casulla de lo mismo que la antecedente y sus recados con la cenefa de tela blanca de matiz--- 
Otras dos casullas con manípulos y estolas y guarnición que la antecedente y de la misma tela con las cenefas de glasé azul de plata---

Un terno de tafetán carmesí bordado, muy viejo---

Otra casulla de damasco blanco, estola y manípulo y cenefa de tela blanca y matiz con galón de seda---

Otra casulla de tela de oro blanco y cenefa de glasé de plata azul guarnecida de galón de oro viejo---

Otra casulla de damasco blanco y carmesí con los mismos recados que la antecedente vieja---

Otras cuatro casullas de picote carmesí con sus manípulos y estolas viejas---

Otras ocho casullas de desecho que por inútiles no se expresan atadas, todas con un cíngulo viejo---

Otras cuatro casullas de raso verde y blanco con flores de matiz, con forro de lienzo azul más servidas e inútiles que las antecedentes---

Otras dos casullas de tela verde y dorada muy antigua con guarnición de galón de oro estrecho y fleque de seda--

Otra casulla, manípulo y estola de raso liso verde, bordada de realce de oro con fleque de seda azul---

Otra casulla de terciopelo rayada, verde, vieja, con cenefa de raso liso carmesí bordada de oro---

Otra casulla encarnada y blanca con galón y fleque de oro fino viejo---

Otra casulla de damasco verde, lo mismo que el antecedente---

Otras tres casullas inservibles y algunos pedazos de otras para remiendos---

Una atrilera de damasco carmesí con bordado antiguo---

Un paño de púlpito de damasco morado viejo---

Un paño de sobremesa de damasco carmesí con cenefas bordadas, viejo---

Un paño de púlpito de raso liso blanco viejo---

Un terno negro entero, la casulla y dalmáticas de felpa, la capa de los mismo rayadas, paño e facistol de espumillon, y atrilera de damasco todo guarnecido de galón de sedas color de oro menos la atrilera---

Otras dos casullas de damasco negro con cenefas encarnadas de tela de oro todas viejas-

Cinco bolsa de corporales nuevas de tela de seda negras---

Seis paños de cáliz negros nuevos de diferentes telas de seda---

Una bolsa y paño de glasé de plata campo negro viejo---

Un paño para tumba de glasé de plata campo negro y fleque blanco y negro---

Dos bolsas de tela encarnadas y carmesíes viejas---

Otras nueve bolsas de distintas telas blancas---

Otras doce bolsas de diferentes colores viejas---

Veintiuno paños de cubre cáliz de distintas telas viejas---

Una banda vieja de comulgar de tafetán azul---

Dieciocho sobrepellices de lienzo delgado nuevos pero estrenados---

Veinticinco sobrepellices usados con algunos remiendos de diferentes lienzos delgados- 
Trece corporales de lienzo mas ordinario sin hijuelas y con encajes de la misma clase nuevos---

Otros diez corporales de lienzo ordinario sin hijuelas usados---

Siete palias para los corporales viejas---

Tres palias viejas y sucias---

Otros tres corporales de lienzo ordinario usados---

Cuarenta y seis purificadores de lienzo nuevos y usados sucios---

Otros treinta y cuatro purificadores de la misma clase limpios---

Quince cornualtares ordinarios nuevos y viejos---

Veinte y tres amitos ordinarios con cintas y cordones---

Otros cinco amitos ordinarios sin cintas ni cordones---

Otros ocho amitos de lienzo fino con encajes y cintas correspondientes---

Nueve cíngulos de hilo usados---

Uno de cinta de tisú verde con fleques de plata viejo---

Otro cíngulo viejo de cinta de teletón antigua---

Otro cíngulo de cinta negra con cabos de hilo de plata---

Otro cíngulo negro con cabos de fleque de oro---

Una corta porción de listones encarnados usados---

Sesenta y tres hijuelas redondas de diferentes colores viejas---

Quince hijuelas cuadradas de diferentes colores usadas---

Veinticuatro hijuelas de lienzo blanco con encajes de diferentes clases---

Otras dos redondas nuevas, la una bordada de oro con un corazón y la otra de tela de oro con encajes de plata---

Una muceta de damasco carmesí con galón de oro vieja---

Una sobremesa de tafetán pajizo vieja---

Un palio de tafetán blanco con guarnición de fleque de seda del mismo color---

Una banda de tafetán blanco usada---

Otra lo mismo que la antecedente vieja---

Tres, al parecer, cubre mesa de lienzo viejo---

Un paño de manos de lienzo fino con encajes anchos finos para el terno---

Un alba de lienzo fino con encajes viejos---

Cinco albas de batistilla con encajes ordinarios estrechos nuevos todas en un arca de la antesacristía---

Ítem en otra arca con cerradura y llave de la misma sacristía se encontró lo siguiente--Seis albas de gambano con encajes entre anchos usadas---

Otras seis albas más finas y nuevas que las antecedentes con encajes entre anchos--Otra alba de batistilla vieja con encajes estrechos---

Cinco manteles de alemanisco para altar finos con encajes estrechos nuevos---

Tres manteles de batistilla con encajes entre anchos usados--- 
Otros dos manteles más finos y viejos---

Otros tres pares de lienzo de lo mismo y encajes usados---

Dos paños de comulgatorio de lienzo ordinario como cuatro varas de largo cada una, viejas---

Otras cuatro de la misma largaría de batistilla con encaje entre fino usadas---

Otros dos paños de comulgatorio estrechos de batistilla con encajes usados---

Otros dos pares de comulgatorio de tafetán de llamas, viejos---

Dos manteles de altar de batistilla viejos con encajes antiguos---

Otros manteles de batistilla fina con encajes usados---

Otros como los antecedentes---

Otros de gambano con encajes estrechos usados---

Otro par de batistilla con encaje estrecho usado---

Otro par de batistilla fina con encaje fino antiguo viejo---

Otro par de gambano viejo---

Dos pares de manteles de batistilla con encajes viejos---

Once palias de distintos lienzos usadas---

Diez cornualtares nuevos y servidos---

Una sobremesa de batistilla con encajes usada---

Dos paños de copón de lienzo delgado con encajes ordinarios usados---

Una toalla de batistilla con el segundo terno---

Cuatro toallas para la sacristía de gambano de cuatro varas cada una---

Ítem en otra arca pequeña en la misma sacristía con cerradura y llave se halló lo siguiente-

Un paño de copón de tela con flores de oro, campo oscuro, guarnecido de galones de plata y cinta de oro--

Otro, campo blanco, bordado de matiz y oro con encajes de lo mismo---

Otro de tela campo azul con flores y cinta de oro viejo---

Otro de tela encarnada con plata y cinta y galón de lo mismo---

Otro azul, bordado, viejo---

Dos cortinas de sagrario de tela de oro y matiz, campo oscuro y galón de gasa de plata nueva---

Otra de raso liso blanco bordado de matiz oro y plata con encaje de lo mismo---

Otro de dos hojas, tela de plata antiguo y galón de oro---

Un roquete de cambrayón con bordadura de oro y encaje fino ancho nuevo---

Un alba fina de clarín labrado con fino de cuatro dedos---

Otro roquete de lienzo fino usado con encajes---

Una camisa interior de lienzo delgada usada---

Dos formones, dos hierros y un molde para cortar ostias---

Un ostiario de bronce con su tapa--- 
Trece campanillas de bronce con sus mangos---

Dos cajas de ostiario de hoja de plata---

Un reloj de arena pequeño de media hora---

Una caja de cartón forrada en tela para los vasos de los copones---

Una caja de madera para las hostias---

Seis candeleros medianos de bronce con una cruz y un crucifijo de lo mismo---

Otros siete candeleros del mismo metal más pequeños---

Un azafate de mimbre y dentro de él, un cerco de flores de seda con alguna interpolación de otras de oro y plata de la custodia nueva---

Una porción de rosas contrahechas---

Otro tabaque y dentro de él varias reliquias---

Dos canutos de vidrio con remate de madera dorados y dentro unas reliquias---

Otros dos canutos de vidrio con engaste de hojalata dorado también con reliquias---

Un escritorio con diferentes gavetas pequeñas sobre el mostrador del cajón de los vestuarios varios---

En el mismo lienzo de pared y sobre él, medio del respaldo de dicho encajonado de vestiduras, una lámina como de tres palmos de largo con marco dorado y vidrio con un rostro del salvador---

Un crucifijo grande de madera con su dosel y al pie un cuadro pintura fina de Nuestra Señora con marco negro y dorado---

Dos manos con pedestales de tres caras y vidrios de relicario---

Dos espejos de vestir con marco dorado y coronación de talla como de tres palmos de lino---

Una capilla: un altar con dos frontales viejos y sobre él un pedazo de retablo dorado con una caja de Sagrario vieja con dieciocho relicarios embutidos en vidrio---

Un cuadro de Nuestra Señora y San Juan, pintura fina y una vara de alto y tres palmos de ancho con marco de talla dorado nuevo y con un dosel azul viejo---

Una bandera de Damasco blanco y asta y una cruz de madera vieja---

Doce láminas de diferentes pinturas y marcos viejos---

Un estandarte de Damasco azul viejo con una pintura del Santo Simón---

Un crucifijo de cartón en una cruz de madera negra de más de vara de alto---

Otro de cartón más pequeño que el antecedente---

Diez tablillas de jubileos---

En otro cuarto de bajo ensanche de la sacristía se halló lo siguiente---

Una arca vieja con llave y cantoneras de hierro---

Una mesa pequeña y sobre ella un brasero de mano de hierro con unas luces de latón para chocolatera---

Una tinajita pequeña con agua bendita---

Una regadera de hojalata y tres fuentes de latón para las lámparas---

Otra arca de madera cerrada que se dijo ser a la Anunciata y tener cera en corta porción dentro de ella, de la misma cofradía---

Cuatro sillas de respaldo de Anea sus asientos que sirven en dicha sacristía--- 
Otras tres de corte de tijeras---

Otras tres de respaldo de baqueta viejas unas y otras---

Una mesa de pino pequeña---

Un velón grande de metal dorado con pantalla y dos mecheros---

Una arca con dos cajones, cerradura y llave y dentro lo siguiente---

Cuatro hachas de cera de peso de nueve libras y media

Una porción de cera en cabos menudos y algunas velas de peso de catorce libras y media-

Un cirio Pascual con sus granos de incienso y con peso de siete libras---

Una talega de lienzo virado para recoger la cera---

Sobre los cajones de dicho vestuario diez misales nuevos con tapas negras---

Otros once misales viejos corrientes---

Un breviario grande del tamaño de los misales viejos con forro encarnado---

Una casulla, estola y manípulo de tela blanca vieja con oro y cenefa encarnada---

Otra casulla de raso con galón de seda vieja---

Otra casulla de raso liso morada vieja---

Una bolsa de corporales de tela blanca, bordada, vieja y paño de cáliz---

Otra bolsa morada y paño de cáliz, vieja---

Un alba de lienzo ordinario con encajes nuevos---

Unos manteles y cornutaltar---

Un atril con su misal grande---

Diez cuadros grandes con diferentes pinturas que sirven de adorno a dicha sacristía---

Una cabeza de hojalata---

Cuatro cíngulos de seda viejos---

Y seguidamente dichos señores pasaron a una sala que se halla en el atrio de la citada casa, y en ella abrieron dos arcas de las que sacaron distintas alhajas de plata que por ante mi dicho notario entregaron al citado D. Pablo Franco, y son en la forma siguiente---

Primeramente una lámpara de plata con un rótulo que dice ser de la congregación su peso seis libras y cinco onzas---

Una custodia sobre dorada de plata y guarnecida de algunas piedras vastas y diferentes colores que pesan cinco libras y once onzas---

Un copón grande de plata sobre dorada con tapa de lo mismo granado de cincel de peso de seis libras y ocho onzas---

Otro copón con dos vasos dentro de plata sobre dorada liso de peso de tres libras y doce onzas---

Un cáliz labrado en blanco, con su patena, de peso de una libra, seis onzas y ocho adarmes.

Otro cáliz de plata, en blanco liso y patena de peso de una libra, cuatro onzas y ocho adarmes---

Otro cáliz de plata liso, en blanco, con su patena de peso de una libra, cuatro onzas y cuatro adarmes---

Otro cáliz de plata liso en blanco con su patena de lo mismo, su peso una libra, cuatro 
onzas y ocho adarmes-

Otro cáliz de plata liso sobredorado con su patena, su peso de una libra, trece onzas y seis adarmes---

Otro cáliz de plata, liso, blanco, con su patena y peso de una libra, seis onzas y ocho adarmes---

Otro cáliz de pie de bronce, copa y patena de plata sobre dorada, su peso una libra y quince onzas---

Una cruz de plata grabada con Cristo y Concepción, su peso siete libras y nueve onzas-Un tarro de plata en blanco labrado su peso una libra y trece onzas---

Un vaso grande de plata en blanco liso, su peso una libra, siete onzas y cuatro adarmes-Un par de vinajeras y platillo de plata en blanco liso, su peso una libra, cinco onzas y cuatro adarmes---

Otras vinajeras con su salvilla y campanilla de plata sobre dorada, su peso de dos libras, doce onzas y doce adarmes---

Un par de vinajeras grandes lisas en blanco y un platillo de pie, su peso de dos libras, cuatro onzas y doce adarmes---

Una fuentecica de plata lisa, su peso de dos libras, una onza y doce adarmes---

Una caldereta e hisopo de plata, en blanco liso, su peso de tres libras y doce onzas---

Un incensario con su naveta y cucharita de plata en blanco, su peso dos libras, catorce onzas y ocho adarmes---

Dos varas de ciriales con cuatro cañones cada una y alma de hierro, su peso seis libras y ocho adarmes---

Dos candeleros lisos de plata en blanco, que arman los ciriales, su peso cinco libras y ocho onzas, con espiga de bronce dentro---

Dos bujías y dos campanillas de plata en blanco, lisas, su peso dos libras y tres onzas--Una cruz con su pie en blanco, lisa, de plata, su peso cinco libras y doce onzas---

Dos candeleros compañeros de la cruz en blanco, lisos, de plata, su peso incluso las espigas de hierro de su armadura, el de doce libras y doce onzas---

Una diadema cerrada y una aureola toda en blanco y un cerco de estrellas con peso de once onzas y seis adarmes---

Un escudo de Dulce Nombre de Jesús de plata en blanco con cerco de estrellas y piedras falsas con peso de once onzas y doce adarmes---

Doce cucharitas de cáliz de plata, con peso de una onza y ocho adarmes---

Dos crucecitas sueltas sobre doradas de sobre copón, con otra media cruz mayor del mismo y están con dos piedras falsas, todo su peso de dos onzas y doce adarmes---

Seis ramos de flores de plata en blanco, labrados de cincel, con peso de una libra y doce onzas---

Un Corazón de Jesús de metal, esmaltado, encarnado con el viril de oro que por su hechura no se pudo sujetar al peso---

Un cáliz y patena en blanco, que servía en la Capilla de Comunidad, su peso una libra, tres onzas y seis adarmes---

Un ramo de azucenas de plata, del uso de la imagen de Señor San Javier, con peso de tres libras, digo de catorce onzas--- 
Una lámpara grande de la Capilla mayor de dicha Iglesia, labrada de cincel, con peso de nueve libras y doce onzas---

Otra lámpara de la Capilla de Nuestra Señora del Socorro, también de plata labrada, con peso de seis libras y seis onzas---

Otra lámpara compañera de la antecedente y de la misma capilla, con peso de seis libras y dos onzas---

Otra lámpara de la Capilla de Señor San Francisco Borja, con peso de tres libras y doce onzas---

Otra lámpara de la Capilla de Señor San Ignacio, con peso de cuatro libras y doce onzas, digo nueve onzas-

Dos arañas de plata en blanco con seis mecheros cada una, del uso y adorno de la misma Capilla y su peso las dos de cinco libras y doce onzas---

Una lámpara de plata de la Capilla del Santo Cristo de la Buena Muerte, con peso de una libra y ocho onzas-

Dos arañas de plata con tres mecheros cada una y cercos de hojalata para recibir la cera, del uso y adorno de dicha capilla, con peso ambas de una libra y once onzas---

Dos arañas de plata con seis mecheros cada una y el arma de madera, del adorno del altar de San Ciro, colateral de la misma capilla del Santo Cristo, ambas con peso de cinco libras y doce onzas---

Otra lámpara de la Capilla de San Francisco Javier, con peso de tres libras, nueve onzas y ocho adarmes---

Otra lámpara compañera de la antecedente y de la misma Capilla, con peso de dos libras y nueve onzas---

Dos arañas del adorno de dicha Capilla de plata en blanco, con peso ambas de una libra y siete onzas---

Dos ampolletas para los santos óleos, con sus punteros, todo ello de plata y con peso de cuatro onzas---

Cuyos bienes y alhajas (...). En esta ciudad de Murcia a tres días del mes de Noviembre (...)

El retablo antiguo de cuatro cuerpos y el tabernáculo nuevo con sus gradas y pedestales dorados con dos imágenes pequeñas de San Pedro y San Pablo dorado también

Dos láminas ovaladas con medias cañas doradas de los Corazones de Jesús y María.

Una imagen de talla de San Pedro y San Pablo = Otra de San Javier = Otra de San Esteban $=$ en el nicho principal $=$ otra de San Ignacio con un viril de plomo en la mano $=$ otra de San Pedro, todas de talla y cuerpo entero = cuatro espejitos pequeños con marcos dorados = cuatro láminas ochavadas, pinturas de flores finas, con marcos de cristal y vidrio hilado $=$ dos arañas pequeñas de madera $=$ una imagen de San Juan $=$ otra de San Sebastián = otra de Nuestra Señora con corona de Plata = otra de San Juan Bautista $=\mathrm{y}$ otra de Santiago $=$ un crucifijo grande de talla $=$ San Juan y Nuestra Señora $=$ dos barrenos de hierro para el velo de semana de Pasión que cubren todo el retablo $=$ dos corazones de lienzo morado para este efecto viejo---

Un frontal de talla, dorado, sobre cristales de espejo. Un ara de mármol---

Un atril de madera en blanco---

Dos candeleros o bujías de madera plateada vieja---

Tres tablillas de los Sagrados Cánones--- 
Sacra y Evangelio de San Juan---

Tres badanas de sobre altar---

Un crucifijo de cartón con su pedestal, todo viejo---

Un manifestador de fábrica moderna, de talla dorado, con viril de lo mismo---

Una cuerda de cáñamo para la lámpara en dos listones de madera---

Un bufete cuadrado de piedra para las vinajeras---

Un pedestal de madera de talla, dorado, para poner a su majestad. Reservado el jueves santo---

Una cruz para el altar mayor de Jerusalén, embutida en nácar---

Tres gradas de madera para subir al altar mayor---

Dos varas de hierro con dos pilares de lo mismo, para los paños del comulgatorio, cuatro varas de madera con respaldos grandes---

Diez cuerdas de cáñamo gruesas, para subir los bastidores de la colgadura---

Capilla de San Javier

Un altar de madera en la Capilla de San Javier con un ara y tres badanas con que se hallaba cubierto---

Un atril de madera viejo---

Tres sacras con marcos dorados---

Un sagrario de madera antiguo y dorado---

Una cruz de madera con algunos embutidos de nácar, al parecer de Jerusalén---

Varios relicarios embutidos en la madera del retablo sobre dicho altar con vidrios unos y otros sin ellos---

Un retablo de talla dorado antiguo---

Un velo de tela con flores de matiz, friso de lo mismo, manillas de bronce y guarnición de encaje de plata falso---

Siete milagros de plata de varios tamaños en dicho retablos colgados en las columnas de él---

Dos floreros de seda, viejos---

Cuatro candeleros grandes de madera plateados---

Otra corona más pequeña pero de la misma fábrica y circunstancias que tenía puesta el Niño---

Una encomienda de Santi Espíritu esmaltada en blanco sobredorado---

Un caldero puesto en la ropa del Niño y un relicario pequeño de lo mismo---

Un guardarropa, al parecer de nogal, con embutidos de medio cuerpo y cerradura y llave, y dentro la ropa del uso de dicha imagen y Niño que es la siguiente---

Un vestido compuesto de manto, túnica y vestido del Niño de tapicería, campo blanco con flores de matiz guarnecido de encaje de oro todo ello y forrado en tafetán garzota--Otro vestido con las mismas piezas que los antecedentes, de tela de tapicería verde, el campo guarecido con encaje de plata esmaltado y forrado en tafetán de color de oro---

Otro vestido con las mismas piezas que los antecedentes, de tela de oro, campo verde guarnecido de galón de oro y forro de tafetán encarnado---

o Otro vestido de las mismas piezas, de tela de oro, campo azul guarnecido de galón de 
plata, forrado en tafetán azul viejo---

Otro vestido entero como los antecedentes, de griseta, encarnado con guarnición de blonda de oro, como de media vara de ancha, y otra orden de estrecha y forro de tafetán garzota todo nuevo---

Otro vestido con las mismas piezas, de tela de oro, campo blanco guarnecido de encaje de oro y forrado en tafetán de color, de garzota nuevo---

Otro vestido compuesto de las mismas piezas, de tela de oro, campo encarnado antiguo, forrado en tafetán, encarnado viejo---

Dos camisas de lienzo delgado de dicha soberana imagen y una de la del Niño---

Ocho pares de vuelos finos, unos con encajes y otros bordados sin ellos---

Una caja de madera y, en ella, un rosario de piedra ágata engastada en plata con una Cruz de Jerusalén, guarnecida de plata sobre dorada---

Otra caja con diferentes lazos de cinta de diversos colores---

Otra caja con una porción de flores contrahechas de seda y lienzo---

Una media luna de plata grande a los pies de dicha Santa Imagen---

Y en dicho camarín: dos arañas de plata de martillo pequeñas con tres mecheros cada una Cinco láminas pequeñas, ochavadas, con marcos de cristal y vidrio, pintados de florero--

Cuatro relicarios de tres caras, grandes, de madera dorada, a forma de pirámide con diferentes vidrios embutidos y reliquias---

Y en el ante camarín dos laminitas de cobre pintadas de San Juan y Nuestra señora con marcos dorados antiguos---

Otro relicario a forma de lámina de madera dorada con vidrios y reliquias embutidos---

Una imagen de la Purísima de talla pequeña con una corona de plata---

Una cruz de madera negra---

Una urna pequeña y ordinaria con un Niño Jesús dentro de ella---

Una caja de ébano embutida en concha marfil y nácar, con llave y escudo de plata en la cerradura y otra moldura de lo mismo en la cornisa y basa del frontis de ella, la cual es la que sirve para sagrario del monumento el Jueves Santo---

Un Agnus Dei embutido en un óvalo de madera con su pie---

Otro relicario de madera con algunos vidrios y reliquias embutidos---

Una escusabaraja con ocho ramos pequeños de flores contrahechas de Génova y otros seis de papel ordinario---

Ítem del retablo de dicha capilla, de talla dorado y los lisos jaspeados de azul con dos imágenes a los lados de San Joaquín y Santa Ana, de talla en nichos de espejos y con sus cubiertas de lienzo y pintura de las mismas imágenes. Encima de dicho retablo, una imagen de medio cuerpo, con un relicario grande en el pecho que, según se manifestó, contenía las reliquias de San Juan Presbio Mártir---

Otro lienzo con una pintura de San José por remate de dicho retablo, que este comprende el testero de dicha capilla y colaterales de ella, en los cuales hay un cuadro grande del trasunto de Nuestra Señora y otro del nacimiento de su Divina Majestad---

Dos mesas de piedra bruñida, cuadradas, con pies de lo mismo---

Capilla del Santo Cristo

Un altar con su ara y sobre él, tres badanas, una sacra y dos tablillas de Evangelio, un 
atril de madera, dos candeleros de lo mismo, con frontal de talla dorada, embutidos en cristales---

Un retablo principal de talla dorada y jaspeado de azul, y el nicho de espejos---

Un Señor crucificado grande de efigie primorosa, en cruz de madera negra con velo de pintura---

Una imagen de Nuestra Señora de los Dolores, de talla mediana, con espada y diadema de plata---

Otra imagen de San Juan de la misma fábrica y tamaño sin adorno alguno---

Un tabernáculo de talla dorado, con una puerta de cristal y dentro de él, una lámina pequeña de piedra ágata, con una imagen de la Purísima Concepción con los llanos de vidrio, mitad lápiz azul y el marco de ágata morada y vetas, toda guarnecida de metal dorado en fuego y sobre puesto de lo mismo, con antorchados de plata en blanco---

Otro altar en un colateral de dicha capilla, con retablo de talla dorado y un cuadro de San Juan Nepomuceno y el altar con ara, tres badanas, una sacra y dos evangelios, un atril y dos candeleros viejos---

Otro colateral, con retablo de talla dorado, con una pintura de San Ciro, ocho candeleros de madera dorado-

Un altar con sacra y dos tablillas, tres badanas, ara y un bastidor para el frontal de moldura dorado---

Una mesita de pino pequeña para las vinajeras---

Varios lienzos de milagros pintados y otros de cera---

Capilla de San Luis Gonzaga

Una imagen del santo en un retablo pequeño y antiguo, y en el remate un cuadro al parecer de San Francisco Javier---

Cuatro candeleros grandes de madera plateados---

Una cruz de madera negra con peana embutida vieja---

Un velo de dos hojas de tafetán listado---

Un altar con ara, tres badanas, un atril y dos candeleros de madera y una sacra---

Cuatro gradas de diferentes pinturas antiguas y marco dorado viejo---

Capilla de San Francisco de Borja

Una imagen grande del santo, de talla, con diadema vacía de plata, en un retablo grande de talla dorado y jaspe imitado, y nueve pinturas en lienzo embutidas, de la vida y conversión a la religión---

Cuatro candeleros grandes de madera plateados---

Una cruz de madera dada de azul---

Un altar con ara y una tablilla, y atril de talla dorado con tres badanas y dos candeleros de madera---

Un cuadro grande situado en el testero de la Iglesia con marco negro de los tres mártires del Japón---

Un pie de madera con una lámpara de vidrio---

Capilla de San Pedro

Una imagen del santo pintada en lienzo, antigua---

Otras seis imágenes de diferentes santos pintadas en tabla--- 
Un Niño Dios y otro de San Juan, de talla, todo embutido en un retablo antiguo, dorado y estofado, con tabernáculo y cruz de la misma fábrica---

Un altar con ara, tres badanas, una sacra y dos evangelios con molduras doradas.

Dos candeleros de madera---

Un atril de talla dorado---

Cuatro cuadros, dos grandes y dos pequeños al lado de dicho retablo con marcos negros viejos embutidos en la pared colateral del evangelio---

Nueve láminas en lienzo de diferentes pinturas antiguas y sobre ellas, tres pirámides de madera doradas, que manifiestan ser relicarios---

Nueve láminas como las anteriores con otras tres pirámides del colateral de la Epístola.

Una lámpara de bronce dorado, pequeña, vieja---

Capilla de San Ignacio

Una imagen del santo, de talla grande---

Un retablo de talla dorado, sobre azul, y en el segundo extremo, una pintura de Nuestra Señora---

Un altar con ara, tres badanas, atril y dos candeleros de madera, una sacra y dos tablillas de los Evangelios-

Una urna puesta en el lugar del Sagrario, de madera, con molduras doradas y jaspeadas, con puerta de cristal y lo mismo a los lados, y dentro una lámina, como de media vara de alto y una tercia de ancho, pintura de Nuestra Señora y el Niño de medio cuerpo con cristal muy fina---

Una crucecita de nácar, con engaste de cobre sobredorado, y un crucifijo, lo mismo, adornada dicha urna de diferentes flores contrahechas, forrado el techo de terciopelo azul con sobrepuestas bordadas, estrellas y guarnición de galón, todo de plata y sobre dicha urna, un pabellón para cubrirla, de tela de seda y matiz campo morado y guarnecido de encaje de plata---

Un frontal de talla, dorado, con cristales embutidos---

Un cuadro grande de San Javier, pintado en lienzo, jaspeado el marco, puesto al colateral del evangelio---

Un escaño con cajón y dentro una caja con nueve ramos de flores artificiales extranjeras.

Otra caja con seis piecitas de madera y flores contrahechas---

Seis tabaquitos con iguales pomos, algunas mayores---

Dos tarros de barro de Alcora con docena y media de claveles contrahechos cada uno---

Un vaso de vidrio, cuadrado, con pintura y asa, y otro mayor, sin ella, para poner flores, todas de adorno de dicho altar, dedicados por un bienhechor a la Virgen de la urna referida---

Un cuadro de San Ignacio, grande, pintado en lienzo, con marco jaspeado, puesto al colateral de la epístola-

Otro escaño con su cajón, con cerradura y llave, y dentro de él, seis jarros pequeños, de vidrio, cuadrado, con ramilletes de flores contrahechas y dos ramos de las mismas, de papel---

Capilla de San Estanislao

Una imagen del santo de talla mediana en un retablo de talla dorado, estofas y campo azul y en las cornisas dos imágenes, una de San Juan Bautista y la otra de San Onofre, 
pequeñas y antiguas y en medio del segundo cuerpo, un cuadro de Nuestra Señora del Populo embutida---

Un altar con ara, tres badanas, una sacra, dos tablillas, dos candeleros y un atril de madera-

Otros cuatro candeleros grandes de madera plateados---

Un frontal de talla dorado con espejos embutidos---

Un cuadro grande de San Juan, con marco azul y molduras doradas, puesto al colateral del evangelio---

Tres repisas con tres pirámides, todo de madera, con relicario de vidrio---

Al colateral de la epístola con el mismo marco, otro cuadro de San Lucas, con otras tres repisas y pirámide que el antecedente---

En dicho altar, una cruz de ébano, con perfiles y un crucifijo en ella de marfil---

Trece bancos grandes de respaldo---

Quince confesionarios grandes---

Una mampara de lienzo pequeña---

Un cancel de tableros---

Un púlpito y escalera cerrada, de tableros y sobre él, un guarda voz de talla de fábrica moderna, dorado---

Un listonaje garruchas de madera y cuerdas de cáñamo para poner y subir la colgaduraCuarto detrás de la Capilla Mayor

Ítem en un cuarto en bajo correspondiente al lado de la Epístola de la Capilla Mayor, dos ciriales grandes de madera, molduras doradas---

Un tenebrario con sus candeleros---

Seis esteras de junco pequeñas y estrechas---

Otras dos esteras de junco, finas, grandes para la Capilla Mayor---

Un pie de madera para poner el estandarte---

Once cuerdas gruesas de cáñamo para sujetar los bastidores del monumento---

Seis arañas de madera pintadas de blanco para adorno del monumento---

Una porción corta de pedazos de madera y algunos trastos inútiles---

Una tarimilla de brasero y una vara de cobre---

Una caja muy grande de madera para meter los frontales---

Un ataúd---

Seis varas de madera dadas de blanco para el palio---

Tres docenas de ramos de flores de papel, grandes y pequeñas, con pies de madera plateados y otros dorados, en un armario---

En otro armario dos jarros de barro de Alcora, con una porción de claveles grandes, de lienzo contrahecho $=$ otro jarro de vidrio cuadrado con flores como los antecedentes--Docena y media de flores de papel de diferentes tamaños---

Otros seis viejos con pies plateados---

Un pedestal de madera dorado con diferentes vidrios y reliquias embutidos---

Una cruz de hierro--- 
Dos bancos viejos de madera---

Un cajón grande de madera para las colgaduras---

Ocho frontales de diferentes telas moradas, viejas---

Otro frontal de Damasco, morado, con galón de seda, de color de oro---

Otro frontal de Damasco, morado, nuevo, con galón de oro entre ancho---

Otro frontal de picote morado y bordado de colores, con perfiles de oro y fleque de lo mismo, antiguo y viejo---

Seis frontales de diferentes telas y el campo blanco viejo---

Otro de raso liso blanco, bordado, las cenefas de flores de matiz viejo---

Otros cuatro de campo blanco, bordado antiguo con flores de oro y fleque de seda carmesí---

Otro campo blanco de cenefa bordada, de matiz viejo---

Cuatro frontales negros, de diferentes telas viejas---

Otro de terciopelo negro, viejo, bordado de oro y matiz antiguo---

Otros cuatro frontales con el campo carmesí, bordados con perfiles de oro, viejos---

Otros dos frontales de tela carmesí, viejos---

Otros cuatro frontales, campo encarnado y flores viejas---

Otro frontal, campo encarnado y flores blancas, pintado en lienzo---

Otro frontal, campo carmesí, bordado de oro para el altar mayor, viejo---

Otro frontal sin bastidor puesto en el altar mayor de pintura con fleque y galón de oro---

Dos frontales verdes, con fleque del mismo color y encarnado de seda viejos---

Otro frontal, color verde, de realce de oro y algún matiz bastante usado---

Tres almohadas con fleque, carmesíes, llenas de paja, muy usadas---

Otra cabecera de cáñamo, carmesí, vieja y llena de lo mismo que las antecedentes---

Otra de damasco, carmesí, vieja, llena también de paja---

Otra bordada, antigua, sobre carmesí, muy vieja---

Nueve sillas con asientos de Anea, torneadas, viejas---

En el cuarto de San Javier que esta junto a la Iglesia se encontró una alfombra de seda vieja forrada en lienzo blanco de colores, de tres varas de largo y dos de ancho---

Otra alfombra de Liétor, de colores, de tres varas y media de largo y una y media de ancho vieja---

Otra alfombra de la misma fábrica, vieja, de cinco varas de largo y dos y media de ancho-

Otra alfombra pequeña, de Liétor, muy rota, de dos varas y media de largo y poco más de ancho---

Otra alfombra grande, de la misma fábrica, usada, de cuatro varas de ancho y ocho de largo, que se expresó ser de Doña María Irene Galtero---

Otra alfombra de la misma fábrica, vieja, de colores, de seis varas de largo y dos de ancho a medio usar---

Otra alfombra, muy vieja, de berbería, de cinco varas de largo y dos de ancho---

Dos tapetes pajizos, muy viejos--- 
Otra alfombra afelpada, larga, vieja y rota, de seis varas de largo y dos de ancho---

Otras dos viejas, rotas, de tres varas de largo y dos de ancho, fábrica de Liétor---

Cuatro cortinas de Damasco, carmesí, de tres telas cada una y dos varas de largo---

Un paño de púlpito de seda, campo negro y flores moradas, con galón de seda y fleque blanco, nuevo---

Un dosel de Damasco, carmesí y fleque de lo mismo---

Tres sillas del presbiterio con asientos y respaldos de felpa, carmesí y clavazón dorada, muy viejas---

Dos facistoles viejos---

Tres sillas viejas, pequeñas, con asientos de anea---

Una estatua cabeza y manos de San Juan Francisco---

Otra estatua de San Ignacio---

Otra de San Javier---

Otra con cabeza y manos de marfil, del mismo santo---

Una manga de cruz de felpa negra, con galón de seda pajizo---

Otra manga blanca, bordada, antigua, vieja---

Una colgadura de Damasco y terciopelo carmesí para la Iglesia y Capilla mayor, compuesta de cuarenta paños colocados de dos órdenes en la Capilla Mayor y pilares de ella, los unos sobre los otros, con su cenefa y en la misma disposición, pero de una orden, solamente en todo lo restante de la Iglesia y unos y otros en buen ser, y de todo lucimiento y decencia---

Ítem en el coro de dicha iglesia nueve bancos de ripia sin respaldos---

Un órgano pequeño movible, cerrado, con sus puertas cerraduras y llave corriente---

Un atril de pie de madera---

Un banquillo de mano para el órgano---

Todos los bastidores de lienzo pintado, de perspectiva para el monumento que cubre todo el retablo de la Capilla Mayor, el jueves santo---

Ítem en la torre de dicha Iglesia: un reloj grande de hierro corriente con cuartos y horas-

Una campana grande, de lengua de hierro, barras del mismo y armadura de madera---

Otra pequeña con las mismas circunstancias que la antecedente---

Ítem en el último cuerpo de dicha torre: otra campana del tamaño de la primera, con corta diferencia, sin armadura, ni barras, que sirve para las horas del reloj---

Otra pequeña armadura que sirve para los cuartos---

Ítem en un cuarto en bajo de dicha torre: todas las esteras que sirven para la dicha iglesia y capillas de ella-

Catorce pares de vinajeras de vidrio, con platillos ordinarios, de vidriado de Hellín---

Así mismo en la Capilla de la Comunidad de dicho Colegio, en el altar de ella, un frontal de damasco azul, con bordado antiguo y perfiles de oro viejo---

Un ara, dos badanas, una sacra y dos tablillas pintadas, los marcos de azul---

Dos candeleros de madera y una cruz de lo mismo---

Un retablo pequeño, hechura antigua, con una pintura en medio de Nuestra Señora, y 
a los lados una de San Juan Bautista y otra de los Desposorios de Nuestra Señora, y en el remate otra del Martirio de San Esteban, todas en tabla---

Un cuadro de un Eccehomo, mediano, sin marco, viejo---

Otro de San Javier, con marco negro---

Una lámpara pequeña de bronce---

Catorce cuadros pequeños, de diferentes retratos de algunos barones de la religión---

Otro, mayor que los antecedentes, de otro mártir de la religión---

Dos bancos de respaldo y otro de mano, pequeño---

Cuyos bienes y alhajas dicho señor juez de comisión hizo entrega en la forma referida al citado don Pablo Franco, quien los recibió a su satisfacción y se obligó a tenerlos con toda custodia, y de manifiesto para entregarlos siempre que por el Obispo mi señor u otro señor juez que fuere competente se le mandaran entregar, y a ello obligó sus bienes y rentas habidos y por haber en toda parte y lugar, dio poder a dicho señor y demás señores referidos, para que a ello le apremien como si fuera sentencia definitiva por dicho don Pablo consentida, dada y pasada en autoridad de caso juzgada renuncio las leyes, fueros y derechos de su favor y la general en forma; de los cuales se rebajan los bienes y alhajas siguientes---

\section{RELACIÓN DE ALHAJAS Y ORNAMENTOS QUE TENÍA LA COMPAÑÍA DE JESÚS DE MURCIA Y QUE SE REPARTIERON ENTRE DIFERENTES PARROQUIAS DE LA DIÓCESIS}

Un cáliz todo de plata se dio para la Ermita de Santiago---

Otro también todo de plata para la parroquial del lugar de Iso---

Otro con copa de plata, y pie de bronce dorado se dio para la Ermita de Barqueros Parroquia de Santa María de Murcia; y todos tres se han dado con patena y cucharita---

Se dieron nueve misales uno para la Ermita de Santiago Parroquia de San Miguel de Murcia---

Otro para la Parroquia de la Raya y Puebla de Soto---

Otro para la Ermita de Nonduermas Parroquia de Santa María de Murcia---

Otro para la Parroquia de Pacheco en el Campo de Murcia---

Otro para la Parroquia del Lugar de Iso---

Dos para la Parroquia de San Javier---

Otro para la Parroquia de Alcantarilla---

Otro para la Parroquia de Pozo Estrecho Campo de Cartagena---

Se dieron treinta y tres sobrepellices, tres para la Administración de Sacramentos en la Parroquia de la Raya y de su anexo---

Otro para las Ermitas de Navarros, y Cabezo de la Plata Parroquia de Santa María de Murcia---

Otro para la Ermita de Zeneta de la misma parroquia---

Cuatro para la Iglesia de la Villa de la Alberca Anexo de Santa María de Murcia---

Cuatro para la Parroquia del Lugar de Pacheco---

Cuatro para la Parroquia del Lugar de Iso---

Cuatro para la Parroquia del Lugar de Pozo Estrecho---

Cinco para la Iglesia de Corvera la Alta Anexo de Santa María de Murcia--- 
Dos para la Parroquia de Sucina---

Dos para la Ermita de San Rafael de la Villa de Hellín de donde todavía no ha venido recibo---

Unas vinajeras de plata con platillo de dieron a la Ermita de Santiago anexo de la Parroquia de San Miguel de Murcia---

Se dieron veinte y cinco Casullas; tres para la Ermita de Santiago---

Otra para la Parroquia de la Raya y su anexo---

Dos para las Ermitas de Navarros y Cabezo de la Plata---

Una para la Ermita de Zeneta---

Cuatro para la Parroquia de la Villa de la Alberca---

Dos para la Parroquia del Lugar de Pacheco---

Dos para la Parroquia del Lugar de Iso---

Dos para la Parroquia de San Javier---

Tres para la Parroquia de Pozo Estrecho---

Tres para la Parroquia de Sucina---

Uno para la Ermita de la Virtudes en el Campo de la Matanza Parroquia de Santa María de Murcia---

Otra se deshizo para remendar las que estaban---

Dieron cinco Albas: una a la Ermita de Santiago de esta ciudad---

Otra para la Ermita de Valladolises en el Campo de esta Ciudad Parroquia de Santa María-

Dos para la Parroquia de Pacheco---

Otra para la Parroquia de San Javier---

Las bolsas de corporales, hijuelas, paños de cálices, estolas, manípulos y cosas menudas se dieron con las Casullas, referidas como consta de los recibos aunque no hubo para todas por haberse encontrado faltas---

Como todo lo referido mas en forma consta y parece de dichos autos que por ahora quedan en mi poder y oficio a que me remito, y en fe de ello y en cumplimiento de lo mandado por dicho señor doy el presente que signo y firmo en la ciudad de Murcia a diez y nueve días del mes de Diciembre mil setecientos y setenta.

\section{INVENTARIO DE IMÁGENES, ALHAJAS, ORNAMENTO Y MOBILIARIO QUE TENÍA LA COMPAÑÍA DE JESÚS DE MURCIA EN EL ORATORIO DE LA CASA DE LA ERMITA}

(...) las alhajas del oratorio, que fue de los regulares de la Compañía de Jesús, situado en la Casa de Campo, llamado Ermitas, que son las siguientes $=$ Cinco frontales dorados matizados de azul, y encarnado = Una Imagen de talla de San Juan Nepomuceno, otra de San Antonio de Padua, y otra de la Purísima Concepción todas tres con peanas y como de cuatro palmos de altas $=$ Cuatro lienzos grandes con marcos dorados que servían a los cuatro altares $=\mathrm{Y}$ un retablo dorado con Nuestra Señora del Populo pintada en tabla = que serbia de altar mayor $=$ Cinco cortinas que cubrían los cinco Altares $=$ Cinco Aras $=$ Cinco Atriles $=$ Diez badamas $=$ Quince sacras $=$ Quince Candeleros de madera y ocho de metal $=$ tres cajones o almarios para los recados y creencia $=$ Unos Ramos de Flores para adorno a los Altares = Cuatro cuadros medianos, uno de Nuestra Señora de Belén, otro de Santa Bárbara, otro de San Ignacio de Loyola, y otro del Niño Perdido; Y por ser así lo firmamos para que pueda constar el recibo y entrega de dichas alhajas en Santa Catalina del Monte sobre dicho Convento Recoleto de Nuestro Señor San Francisco de la Regular observancia a 17 de Marzo de 1772 (...). 


\section{INVENTARIO DE BIENES Y ALHAJAS QUE EXISTÍAN EN LA IGLESIA DEL COLEGIO DE LA ANUNCIATA DE CARAVACA DE LA CRUZ}

Lista que se forma por el alcalde mayor comisionado de temporalidades de esta villa de Caravaca con acuerdo y asistencia del señor vicario juez eclesiástico ordinario de ella, de las alhajas de oro y plata que se hallaron y existen en la Iglesia del Colegio de la extinguida compañía pertenecientes a su culto y adorno conforme a la Real Provisión de 6 de marzo de 1773.

Primera Clase.

Una custodia de plata sobredorada que con la madera de su armazón y sin el hierro pesa diez y siete libras y doce onzas---

Un copón con su tapa de plata sobredorada que pesa tres libras, cuatro onzas y seis adarmes---

Dos vasos del copón de plata que pesan quince onzas ambos---

Un cáliz, cuchara y patena de plata sobredorada su peso dos libras y cuatro onzas---

Otro cáliz, patena y cuchara de plata con el pie de bronce que pesa veinte y nueve onzas-

Otro cáliz, patena y cuchara de plata que pesa veinte y ocho onzas---

Otro cáliz, cuchara y patena de plata su peso veinte onzas y doce adarmes---

Una copa de plata su peso trece onzas y doce adarmes---

Una cruz de plata con un Santísimo Cristo de lo mismo sobredorado, su peso cuatro libras, tres onzas y media---

Una ampolla de plata para el olio su peso dos onzas y doce adarmes---

Una urna de plata sobredorada con vidrios y una reliquia de San Bartolomé que pesa dos libras y doce onzas---

Una corona de plata de la Imagen titulada la Niña María que pesa trece onzas---

Seis potencias de plata en dos niños de Nápoles que pesan todas dos onzas y nueve adarmes---

Una diadema de plata con una piedra azul en el medio que es de San Francisco Javier y toda pesa seis onzas---

Segunda Clase.

Un incensario, naveta y cuchara de plata que pesa dos libras y trece onzas---

Dos ciriales de plata su peso siete libras---

Dos candeleros de plata con espigas de hierro y madera que pesan cinco libras---

Cuatro candeleros pequeños de plata de una libra y quince onzas---

Cuatro vinajeras, dos platillos y una campanilla de plata que todo pesa dos libras y cuatro onzas--- 


\section{BIBLIOGRAFÍA}

- Capel, M. (1970). La Carolina, capital de las Nuevas Poblaciones (un ensayo de reforma socioeconómica de España en el siglo XVIII). Madrid: CSIC.

- Fuentes y Ponte, J. (1880). España mariana. Provincia de Murcia. Lérida: Imprenta Mariana (edición facsímil, 2015).

- González Simancas, M. (1905). Catálogo monumental de España. Provincia de Murcia, Tomo II.

- Gutiérrez-Cortines Corral, C. (1976). La Iglesia y el Colegio de San Esteban de Murcia. Murcia: Diputación Provincial.

- Gutiérrez-Cortines Corral, C. (1987). Renacimiento y arquitectura religiosa en la antigua diócesis de Cartagena: Reyno de Murcia, Gobernación de Orihuela y Sierra del Segura. Murcia: Colegio de Aparejadores, 491-514.

- Játiva Miralles, M. V. y Herrero Pascual, C. (2007). La biblioteca de los jesuitas de Murcia (siglos XVI-XVIII). Tejuelo: Revista de ANABAD Murcia, 7, 19-25.

- Játiva Miralles, M. V. (2008). La biblioteca de los jesuitas del Colegio de San Esteban de Murcia. Murcia: Editum.

- López García, M. T. (2010). Aproximación a la gestión municipal del Real Hospicio y Casa de Misericordia de Murcia en el último tercio del siglo XVIII: las temporalidades de los jesuitas. En Campos, F. J., (Coord.), La Iglesia española y las instituciones de caridad. Madrid: Ediciones Escurialienses, 427-452.

- Martín Pradas, A. y Carrasco Gómez, I. (2016). La expulsión de la Compañía de Jesús de Utrera: el reparto de alhajas y bienes inmuebles. Cuadernos de los Amigos de los Museos de Osuna, 18, 53-58.

- Rivas Carmona, J. (1999). Platería cordobesa en Murcia. Imafrornte, 14, 255-272.

- Santos Márquez, A. J. (2011). Los tronos de octavas: una monumental tipología eucarística del antiguo Reino de Sevilla. En Rivas Carmona, J., (Coord.), Estudios de Platería. San Eloy 2011. Murcia: Universidad de Murcia, 519-533.

- VV.AA., (1981). Catálogo artístico y monumental de la provincia de Córdoba. Córdoba: Diputación de Córdoba. 